\title{
Technogenic landforms: conceptual framework and application to geomorphologic mapping of artificial ground and landscape as transformed by human geological action
}

\section{Formas de relevo tecnogênicas: quadro conceitual e aplicação ao mapeamento geomorfológico de terrenos artificiais e da paisagem transformada pela ação geológica humana}

\author{
Alex Ubiratan Goossens Peloggia ${ }^{\text {ac }}$, Érika Cristina Nesta Silva ${ }^{\text {bd }}$, João Osvaldo Rodrigues \\ Nunes ${ }^{\text {be }}$ \\ ${ }^{\text {a} C e n t r o ~ U n i v e r s i t a ́ r i o ~ M e t r o p o l i t a n o ~ d e ~ S a ̃ o ~ P a u l o ~-~ F I G-U N I M E S P, ~ C e n t r o ~ U n i v e r s i t a ́ r i o ~ S E N A C ~ e ~ F a c u l d a d e ~ S E N A I ~ d e ~}$ \\ Tecnologia Ambiental, ${ }^{\mathrm{b}}$ Universidade Estadual Paulista - UNESP, Faculdade de Ciências e Tecnologia \\ calexpeloggia@uol.com.br, derikanesta@yahoo.com.br, ${ }^{\mathrm{e}}$ joaosvaldo@fct.unesp.br
}

\begin{abstract}
The shaping of the Earth's surface by human geological action has produced original landform types, namely technogenic landforms. In this paper we will revise the conceptual framework concerning the geomorphic agency of humankind and introduce a new proposal for classifying these new landforms, which join the existing criteria for the identification of technogenic processes, the analysis of technogenic layers and the characterisation of the resulting newly formed technogenic ground. The proposal itself is enhanced by a taxonomic classification which considers the technogenic landforms as constituent parts of the land shape compartments that, by their way, form extensive technogenic landscapes. The classification was applied to the geomorphologic mapping of two urban areas in Presidente Prudente City (São Paulo State, Brazil) in which technogenic ground occurs.
\end{abstract}

Keywords: Technogenic landforms; Technogenic ground; Man’s geomorphologic action.

\section{RESUMO}

A modelagem da superfície da Terra pela ação geológica do Homem tem produzido tipos originais de formas de relevo tecnogênicas. Neste trabalho é revisado o quadro conceitual concernente à ação geomorfológica da humanidade e introduzida uma proposta de classificação dessas novas formas de relevo, segundo os critérios de identificação dos processos tecnogênicos, as análises das camadas tecnogênicas e a caracterização do resultante terreno tecnogênico recém-formado. A proposta referida é desenvolvida por uma abordagem taxonômica que considera as formas de relevo tecnogênicas como partes integrantes de compartimentos de modelado tecnogênico que, por seu lado, formam paisagens tecnogênicas mais amplas. A classificação foi aplicada ao mapeamento geomorfológico de duas áreas urbanas na cidade de Presidente Prudente (Estado de São Paulo, Brasil) onde ocorrem terrenos tecnogênicos.

Palavras-chave: Formas de relevo tecnogênicas; Terrenos tecnogênicos; Ação geomorfológica do homem.

\section{Introduction}

The main scope of this paper is to promote the discussion about the technogenic landforms - that is, the landforms formed directly or indirectly by human agency -, on one hand as related to genetic processes and, on the other hand, as related to the geomorphic surfaces generated by these processes.

For this to happen it was necessary to revise the knowledge available regarding the subject, which leads us to believe that it is necessary to clear up the issues concerning the results of human geomorphic action.
One of these necessities is just the creation of specific geomorphologic maps able to display adequately the particular effects of the land transformation as promoted by humans and that are affecting extensive regions all over the world, especially in urban areas.

2. The study of the geomorphologic action of humankind

The transformation of the physical configuration of the Earth's surface by human activities implies the creation of particular settings of landforms, known as 
Antropoceno - Tecnógeno

technogenic relief. This action may be considered part of the environmental changes taking place since humankind became an agent of geological proportions, which has since gone global.

The scientific study into human geomorphologic action is in its infancy, despite of the early contributions, for example, of Charles Lyell, in his main book Principles of Geology (Peloggia 2005a). For Lyell, humankind works geomorphologically as a "levelling agent" who tends to plane the relief as a result of joined aggradation and degradation processes.

However, more recently the impacts of human's shaping the Earth's surface have been recognised and described by many authors (e.g. Brown 1970, Drew 1983, Nir 1983, Vita-Finzi 1993, Goudie 1993, 1994, Hooke 1994, 1999, 2000, Rohde 1996, Peloggia 1998, 2005b, Rosembaum et al. 2003, Price et al. 2004, Trenhaile 2004, Peloggia \& Oliveira 2005, Goudie \& Villes 2010, Araújo \& Barbosa 2010, Price et al. 2011, Peixoto et al. 2011). These papers are convergent on the point of the significance of the geomorphic effects of humankind, qualitatively as a direct or indirect creator of new landforms and quantitatively as an agent comparable in capacity (and even superior in his effects) with the natural ones.

As a comparison of human geomorphic action against other landscape transforming agents, Ab’Saber (1969) talked about the modification of the land shape and of the processes that shape the landscape. These processes are in many cases irreversible to the "primary metabolism by nature" (p.2). Already cited by the same author, the human actions affecting the soils, and we can extend this proposition to include the relief, are responsible for various alterations on the land surface that may impersonate, up to a certain point, the climate changes that have occurred during Quaternary times.

Nir (1983) works with the idea of human geomorphologic agency in terms of actions "[...] involving the destruction of the soil cover and the subsequent denudation and erosion" (p.8). Among the factors influencing this "anthropic geomorphology", the author considers that there is a great dependency on social issues, i.e., demographic, economic, and iconographic aspects of humanity.
The author also cited that there are a few cities in which the original land topography has not been altered yet, which may have occurred by three main ways: cuts in the slopes, constructions of embankments and dumping of formerly swamp areas. Among the examples cited, there was the Flamengo embankment in Rio de Janeiro City (Brazil), were the material removed from the hills has been used to extend the shore line out to sea. The modification of Rio's geomorphology by human actions is also referred by Brown (1970).

The studies carried out have produced a general conceptual basis for advanced and systematic research. In this context, one particular open and significant way for increasing knowledge is the development of specific techniques for the geomorphologic mapping of technogenic landforms and landscapes.

Based on the contributions cited above, we agree it is possible to outline a general theory of the technogenic landforms, as indicated by Peloggia (1998, 2005b), which deals with specific geomorphic processes (anthropogenic, anthropogeomorphic or, as adopted in this paper, technogenic) and its resultant landforms and relief shaping.

\section{Technogenic landform classification}

The first step for the establishment of this theoretical conceptual framework is, of course, a general classification, of descriptive character, of the landforms formed through the consequence of human action. Currently there are two main options for classifying these technogenic geomorphic categories: the first (and more simple) one is based on the consideration of the direct or indirect nature of the human action producing or influencing geomorphic processes, as in Brown's (1970) and Haig's (apud Goudie 1994) classifications (tables 1 and 2); the second way is related to the nature of the land surfaces that have been produced, as proposed in the British Geological Survey artificial ground classification (table 3). The landforms produced by direct and indirect manner have been referred as first type and second type technogenic forms by Peloggia (1998, 2005b).

Table 1: Brown's (1970) classification of the human influence upon geomorphologic processes

\begin{tabular}{|c|c|c|}
\hline & HUMAN ACTIONS & EXAMPLES \\
\hline Direct instrument of change & $\begin{array}{cc}\text { Purposeful actions } & \begin{array}{c}\text { Negative forms } \\
\text { Positive forms }\end{array}\end{array}$ & $\begin{array}{c}\text { Highway cuttings } \\
\text { Building of embankments }\end{array}$ \\
\hline Indirect influence & $\begin{array}{c}\text { Incidental consequences } \\
\text { Modification and diversion of geomorphologic processes }\end{array}$ & $\begin{array}{l}\text { Opencast coal working } \\
\text { Quarrying of sand and gravel } \\
\text { Induced mass movements } \\
\text { Soil erosion } \\
\text { Intensification of weathering }\end{array}$ \\
\hline
\end{tabular}

Table 2:- Haig’s classification of major “anthropogeomorphic” processes, according to Goudie (1994) and Goudie \& Viles (2010), lightly modified

\begin{tabular}{cr}
\hline ANTHROPOGENIC PROCESSES & NATURE OF PROCESS \\
\hline Direct & Constructional, excavational, hydrological interference \\
(First type) & Indirect \\
(Second type) & Acceleration of erosion and sedimentation, subsidence (collapse, settling), \\
slope failure, earthquake generation, weathering
\end{tabular}


Table 3: British Geological Survey (BGS) “artificial ground” classification (after Rosembaum et al. 2003, Price et al. 2004, 2011)

\begin{tabular}{ll}
\hline GROUND CLASS & DESCRIPTION \\
\hline MADE GROUND & Areas where material is known to have been placed by humans on the pre-existing natural land surface. \\
WORKED GROUND & $\begin{array}{l}\text { Areas where the pre-existing land surface is known to have been excavated by humans. } \\
\text { Areas where the pre-existing land surface has been excavated and subsequently partially or wholly backfilled by } \\
\text { humans. }\end{array}$ \\
DISTURBED GROUND & $\begin{array}{l}\text { Areas of surface or near surface mineral workings where ill defined excavations, areas of subsidence caused by } \\
\text { the workings and spoil are complexly associated with each other. } \\
\text { Areas where the pre-existing land surface has been extensively remodelled but where it is impracticable to } \\
\text { LANDSCAPED GROUND }\end{array}$ \\
\hline
\end{tabular}

In this paper, it is proposed a third way for classifying technogenic landforms, considering technogenic processes, technogenic layers (all type of superficial formation created directly by or indirectly under influence of Man's geological agency, including deposits or horizons), and the related technogenic ground.
Just in relation to what concerns to artificial ground, Price et al. (2004) proposes an enhancement of the original five categories classification, consisting of a scheme using a hierarchy of classes, types and units, as shown in table 4, in which each level of hierarchy can be subdivided providing progressively more detailed information.

Table 4: Example of the BGS enhanced hierarchic classification (Price et al. 2004)

\begin{tabular}{lll}
\hline CLASS & TYPE & UNIT \\
\hline Made ground & Engineered embankment & Flood defense embankments \\
& Rail embankments \\
& Road embankments \\
& Many further types & Manther types \\
\hline
\end{tabular}

It's remarkable that the "made ground" category has already been described by Sherlock (1922), in his study of the human geological agency in the City of London, as an "incoherent and superficial deposit, analogous in texture and position to a river deposit or glacial drift" (p.334), consisting of débris accumulations, that is, varied masses of "human exuviae of every conceivable kind, mixed with more or less with soil or rock" (p.193), that conforms an artificial surface level.

Taking it into account, in terms of constituent material, the made ground and the infilled ground are formed essentially by technogenic built up deposits, according to the classification of technogenic ground and geological material proposed by Peloggia et al. (submitted).

Furthermore, the BGS classification lacks on the consideration of important types of geological material formed due to human geological agency. For example, there isn't an artificial ground class that represents, without ambiguities, the sedimentary deposits formed under indirect influence of humankind (the induced technogenic deposits), or the surfaces that have been eroded by human induced processes (eroded ground). Or also these ones formed by the superposition of layers of genetically differentiated artificial ground (layered ground). In this ground class, of course, it is necessary to characterise the local technogenic profile (the vertical setting of superposed technogenic layers, that is, technogenic deposits or technogenic soil horizons) and its specific technogenic layering mode (geometric relationship between layers).
This kind of mapping has been used, for example, by Barros \& Peloggia (1993), who proposed detailed geological-geotechnical mapping (1:500 scale) units defined by the superposition of technogenic layers and natural soil horizons.

In this context, the classification of technogenic ground proposed by Peloggia et al. (2014) (table 5a and 5b) enhances the former classifications of artificial ground, including the technogenic deposits and horizons, and provides 13 additional categories of mappable ground, grouped into four main classes.

Be as it may, it is now possible to introduce another way to classify the technogenic landforms using, as criterion, the type of movement of the geological material: removal, deposition or in situ displacement. This procedure allows three main genetic categories of technogenic landforms, as displayed in tables 6a and 6b.

So in this context, it's also useful to introduce an integrated classification to what joins the three former criteria, associating the nature of human action, the nature of the technogenic processes and the associated movement of geological material. The proposal for the new classification is displayed in figure 1 , and the final result is the definition of four main genetically homogeneous geomorphic technogenic land surface types. Each surface type, by its time, may represent different specific landforms related to particular technogenic environments. 
Antropoceno - Tecnógeno

Table 5A: The classification of technogenic ground proposed by Peloggia et al. (2014), resumed and adapted

\begin{tabular}{lll}
\hline CLASS & \multicolumn{1}{c}{ TECHNOGENIC GROUND CLASSIFICATION } \\
\hline Aggraded Technogenic Ground & TYPES & TECHNOGENIC LAYER OR FEATURE \\
& Infilled ground (2) & Technogenic built up deposits \\
& Technogenic sedimentary or wash ground & Technogenic built up deposits covering worked ground \\
& Induced alluvium-like sedimentary technogenic deposits & Induced colluvium-like technogenic deposits \\
& Displaced ground & Remobilized technogenic deposit \\
Degraded Technogenic Ground & Eroded ground & Erosion scars due to induced processes \\
& Slipped or Scared ground through landslides & Slope mass movement scars due to induced processes \\
& Sunken or Disturbed ground (2) & Subsidence sinkholes due to induced processes \\
& Excavated or Worked ground (2) & Excavation surfaces \\
Modified Technogenic Ground & Chemically modified ground & Contaminated soil horizons \\
& Mechanically modified ground & Compacted or revolved soil horizons \\
Mixed Technogenic Ground & Complex ground & Complex technogenic profiles \\
& Layered ground & Composed technogenic profiles \\
\hline
\end{tabular}

(1) In the original sense as cited by Sherlock (1922).

(2) According to the British Geological Survey (BGS) artificial ground classification.

Table 5B: Version in Portuguese of the technogenic ground classification

\begin{tabular}{lll}
\hline & \multicolumn{1}{c}{ CLASSIFICAÇÃO DE TERRENOS TECNOGÊNICOS } \\
\hline CLASSE & TIPO & CAMADA OU FEIÇÃO TECNOGÊNICA \\
\hline Terreno & Terreno produzido (1,2) & Depósitos tecnogênicos construídos \\
tecnogênico de & Terreno preenchido (2) & Depósitos tecnogênicos construídos recobrindo terreno escavado \\
Agradação & Terreno tecnogênico sedimentar aluvial & Depósitos tecnogênicos sedimentares induzidos de tipo aluvial \\
& Terreno tecnogênico sedimentar coluvial & Depósitos tecnogênicos induzidos de tipo coluvial \\
& Terreno remobilizado & Depósitos tecnogênicos remobilizados \\
Terreno & Terreno erodido & Cicatrizes de erosão criadas por processos induzidos \\
tecnogênico de & Terreno escorregado ou marcado por cicatrizes de & Cicatrizes de escorregamentos criadas por processos induzidos \\
degradação & escorregamentos & \\
& Terreno movimentado ou afundado (2) & Depressões de subsidência criadas por processos induzidos \\
Terreno & Terreno escavado (2) & Superfícies de escavação \\
tecnogênico & Terreno quimicamente alterado & Horizontes de solo contaminados \\
modificado & Terreno mecanicamente alterado & Horizontes de solo compactados ou revolvidos \\
Terreno & & \\
tecnogênico misto & Terreno sobreposto & Perfis tecnogênicos compostos \\
\hline
\end{tabular}

(1) No sentido original atribuído por Sherlock (1922)

(2) De acordo com a classificação de terrenos artificiais do Serviço Geológico Britânico.

Table 6A: A proposal on the genetic classification of technogenic landforms based on the displacement of geological-technogenic material criterion

\begin{tabular}{|c|c|c|}
\hline MAIN CATEGORIES & GENESIS & ORDINARY TYPES \\
\hline Aggraded & Land surfaces produced through building up processes due to & (1) Sedimentary-like depositional landforms \\
\hline Landforms & $\begin{array}{l}\text { accumulation of material, namely landfilling, or by } \\
\text { intensification of sedimentary deposition. }\end{array}$ & (2) Landfills and dumps in general \\
\hline Degraded & \multirow{3}{*}{$\begin{array}{l}\text { Land surfaces produced or modified by the removal of geologic } \\
\text { material: directly by human mechanical action or indirectly by } \\
\text { human intensification of erosion, or even by natural erosion of } \\
\text { ancient technogenic deposits. }\end{array}$} & (1) Natural surfaces that suffered induced accelerated \\
\hline \multirow[t]{2}{*}{ Landforms } & & erosional processes \\
\hline & & $\begin{array}{l}\text { (2) Former technogenic deposits further eroded } \\
\text { (3) Directly excavated surfaces }\end{array}$ \\
\hline \multirow{4}{*}{$\begin{array}{l}\text { Disturbed } \\
\text { Landforms }\end{array}$} & \multirow{4}{*}{$\begin{array}{l}\text { Land surfaces and geomorphic systems topographically altered } \\
\text { by in situ dislocation or displacement of geologic material due to } \\
\text { induced superficial or underground mass movements. }\end{array}$} & (1) Natural surfaces that suffered subsidence or \\
\hline & & collapse processes \\
\hline & & $\begin{array}{l}\text { (2) Former aggradation technogenic surfaces further } \\
\text { dislocated }\end{array}$ \\
\hline & & (3) Modified river system patterns \\
\hline
\end{tabular}

Table 6B: Version in portuguese of the proposal of genetic classification of technogenic landforms

\begin{tabular}{|c|c|c|}
\hline PRINCIPAIS CATEGORIAS & GÊENSE & TIPOS COMUNS \\
\hline Formas agradativas & $\begin{array}{l}\text { Superfícies geomórficas produzidas por processos de elevação } \\
\text { topográfica devida à acumulação de material, notadamente } \\
\text { aterramento, ou pela intensificação da deposição de sedimentos. }\end{array}$ & $\begin{array}{l}\text { (1) Formas deposicionais sedimentares. } \\
\text { (2) Aterros em geral. }\end{array}$ \\
\hline Formas degradativas & $\begin{array}{l}\text { Superfícies geomórficas produzidas ou modificadas pela remoção } \\
\text { de material geológico: diretamente por ação mecânica humana ou } \\
\text { indiretamente pela intensificação da erosão, ou mesmo pela erosão } \\
\text { natural agindo sobre depósitos tecnogênicos antigos. }\end{array}$ & $\begin{array}{l}\text { (1) Superfícies naturais que sofreram } \\
\text { processos de erosão acelerada induzidos. } \\
\text { (2) Depósitos tecnogênicos anteriores } \\
\text { erodidos posteriormente. } \\
\text { (3) Superfícies diretamente escavadas. }\end{array}$ \\
\hline Formas movimentadas & $\begin{array}{l}\text { Superfícies e sistemas geomórficos alterados topograficamente por } \\
\text { movimentação in situ de material geológico devida a movimentos } \\
\text { de massa superficiais ou subterrâneos induzidos. }\end{array}$ & $\begin{array}{l}\text { (1) Superfícies naturais que sofreram } \\
\text { processos de subsidência ou colapso. } \\
\text { (2) Formas tecnogênicas agradativas } \\
\text { anteriores posteriormente movimentadas. } \\
\text { (3) Padrões fluviais modificados. }\end{array}$ \\
\hline
\end{tabular}


Antropoceno - Tecnógeno

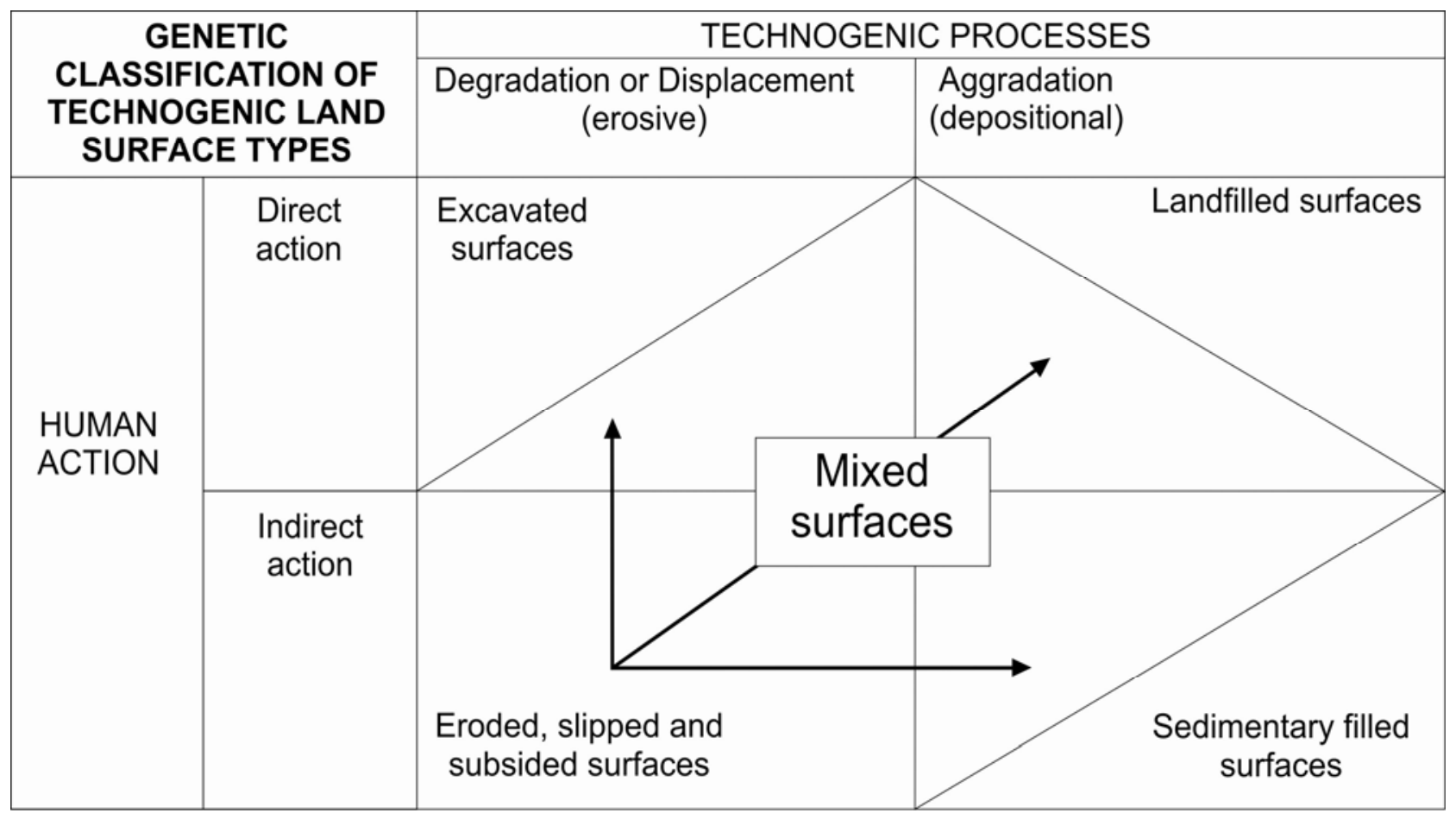

Figure 1: Proposal for integrated genetic classification of technogenic land surface types

After this procedure it's possible to summarize the basic geomorphic technogenic processes that are responsible for the configuration of the technogenic landforms, as viewed in figure 2.

\section{The taxonomic approach and the geomorphologic mapping of technogenic landforms}

In general, the geomorphologic mapping of technogenic landscapes or technogenic ground presents the same main problems concerning geomorphologic mapping. In addition to the shared problems there are other specifically associated questions. One of them is the particularity of the taxonomic issue or, in other words, the relation between the mapping scale and the dimensions of the possible objects presented by cartographic generalisation.

Nevertheless, considering the ground classification proposed by the BGS works, and using the simplified taxonomic proposal from Demek (1965 apud Ross 1992), it is possible to propose a specific approach applied to the technogenic relief cartographic representation. Demek's classification itself joins three levels of mapping: 1) genetically homogeneous surfaces (representing the smaller spatial dimension); 2) landforms (the intermediate dimension), and; 3) relief types. According to Ross (1992), this approach is applied to detailed scales of mapping of 1:5.000 to $1: 10.000$, and because of this limitation it's necessary to add an additional level to be able to feature major spatial dimensions joining up settings of diversified landforms.

Ross (1992) proposes a relief taxonomic classification in which six classes (taxa) are recognized as being: morphostructural units, morphosculptural units; morphologic units or landform patterns; landform types; slope types and contemporary processes related landforms. According to the author, the last class in general includes landforms originated by human induced processes, such as accelerated erosional events. By comparing the landforms produced due to human action with the landform categories proposed by Ross (1992), Peloggia (2005b) writes that it is possible to consider the occurrence of technogenic landforms from the sixth up to the fourth class (landform types). However, a primordial difference is that Ross' classification reveals a strong genetic link among the smaller landforms and the larger ones. But in the specific case of technogenic landforms, according to Peloggia (2005b), the smaller ones may not have any kind of genetic relationship with the larger ones, in terms of generating processes. Following on from this idea, there is certainly a spatial conditioning linking the technogenic land shape with the natural relief compartments, because human geomorphologic action taking place overlaps on former natural landforms.

In this point of view (tables $7 \mathrm{a}$ and $7 \mathrm{~b}$ ), the technogenic landform may be considered as the basic taxonomic category. The technogenic landforms themselves (figure 2) are defined by technogenic land surfaces (related to excavation, landfilling, erosion or sedimentary filling). The technogenic land shapes (figure 3) are settings of various origin technogenic landforms that conform with a specific relief shape found in a certain area. And the technogenic landscapes (figure 4) consist of large areas extensively transformed by geomorphic human action, which include landforms generated by all the four land surface genetic processes. 
Antropoceno - Tecnógeno

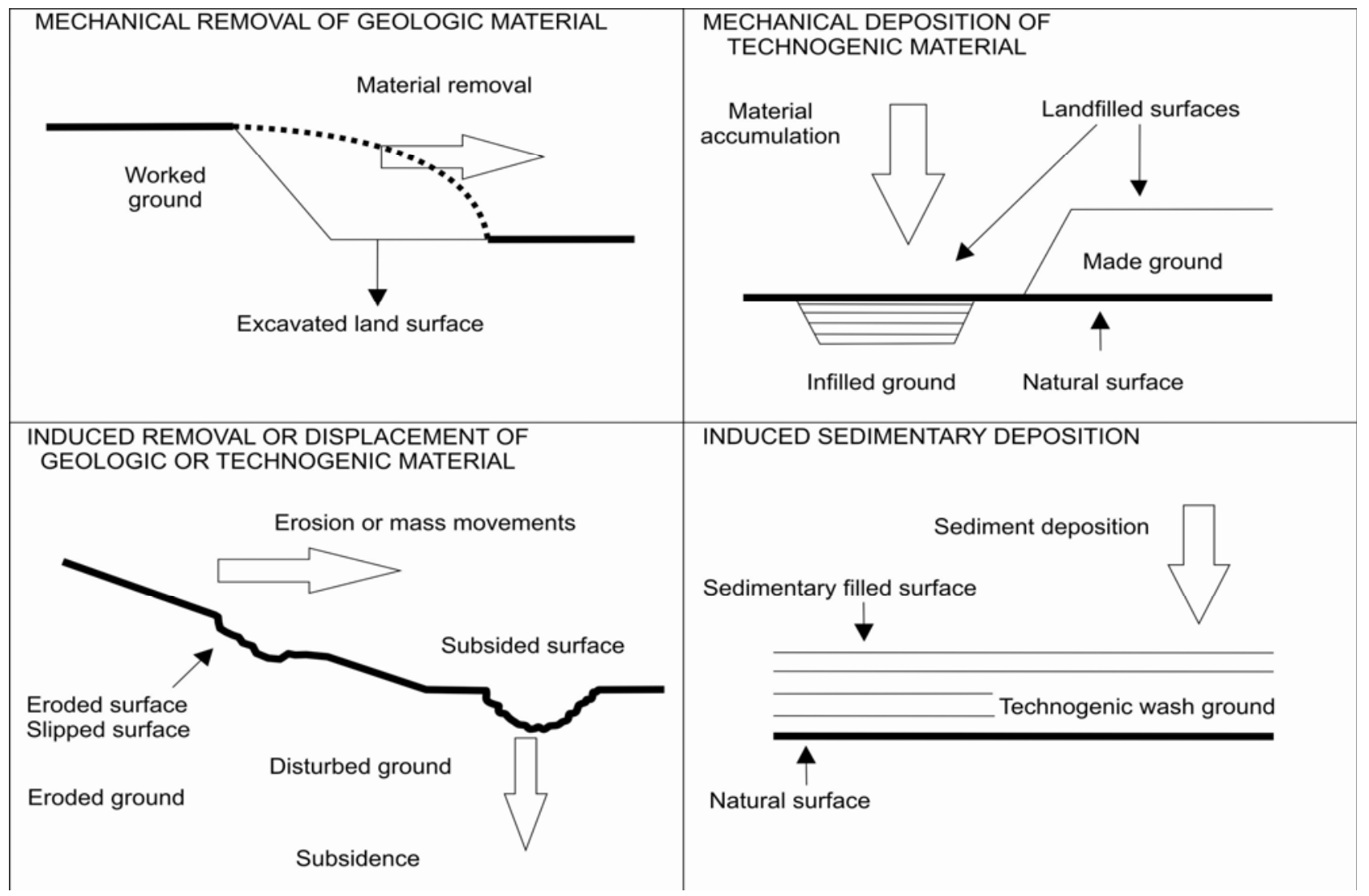

Figure 2: Schematic view of basic geomorphic technogenic processes and related land surface types and technogenic ground

\section{Technogenic Landform mapping in Presidente Prudente City and surroundings (São Paulo State, SE Brazil)}

The City of Presidente Prudente is found within the Paraná Sedimentary Basin Morphostructure and in the São Paulo Western Plateau morphosculpture within it, namely in its Mid-Western Plateau unit (Ross \& Moroz 1997). The rocky substratum is the Adamantina sandstone, a Mesozoic sedimentary formation, which was included into the Bauru Group (IPT ${ }^{1}$ 1981). According to Soares et al. (1980, apud IPT 1981), this formation is composed by finely granulated sand bars alternated with mudstones. The weathering and pedogenesis processes acting over this basement have produced in general sandy soils highly susceptible to erosion.

What concerns the natural relief configuration of the urban area is the predominance of low hills (300 to 600 $\mathrm{m}$ high) with slope declivities of about $10 \%$ to $20 \%$. There is a remarkable difference between the West side and the East side of the area. The West side has larger hills with gently undulated tops and also gentle slopes (declivities varying from 0 to $10 \%$ ), compared to the East side, in which the hills are predominantly shorter with undulated tops and more inclined slopes (declivities from 5\% to 20\%) (Nunes et al. 2006).

Due to the modifications caused by the human activities, specifically in the urban area, the geomorphology and the superficial ground have also been altered. Two areas have been studied in detail, namely the Alexandrina Park and the Industrial District I (Antônio Crepaldi area), in each one of them the occurrence of technogenic deposits have been investigated.

\subsection{Technogenic deposits and techniques of sampling}

The induced technogenic deposits of Alexandrina Park and Industrial District I (Antônio Crepaldi area) have been deposited over hill slopes and their formation can be associated to land use and settlement processes, in particular due to accelerated erosion rates.

Alexandrina Park is a popular residential area, found on the East side of the city (where the slopes are more inclined than in the West side), specifically in the places near the "V" valley flats, which can have only restricted narrow floodplains. In this way it has been made possible the deposition of technogenic layers (induced colluvium-like technogenic deposits) in the slope compartment, producing a particular type of aggraded artificial ground, classified as colluvium technogenic slope ground, according to the Peloggia et al. (submitted) classification.

\footnotetext{
${ }^{1}$ IPT: Instituto de Pesquisas Tecnológicas do Estado de São Paulo.
} 
Antropoceno - Tecnógeno

Table 7A: Proposal for taxonomic classification of technogenic relief

\begin{tabular}{|c|c|c|c|}
\hline $\begin{array}{l}\text { TECHNOGENIC- } \\
\text { GEOMORPHOLOGIC } \\
\text { TAXON }\end{array}$ & $\begin{array}{l}\text { 1. TECHNOGENIC } \\
\text { LANDSCAPES }\end{array}$ & $\begin{array}{l}\text { 2. TECHNOGENIC } \\
\text { TERRAINS } \\
\text { (LAND SHAPE } \\
\text { COMPARTMENTS) }\end{array}$ & $\begin{array}{l}\text { 3. TECHNOGENIC LANDFORM TYPES } \\
\text { AND RELATED } \\
\text { LAND SURFACES }\end{array}$ \\
\hline CONCEPT & $\begin{array}{l}\text { Widespread areas with } \\
\text { extensive typical relief } \\
\text { transformed or produced } \\
\text { by human action }\end{array}$ & $\begin{array}{l}\text { Technogenic features of a } \\
\text { tract of land } \\
\text { (Settings of technogenic } \\
\text { landforms associated with } \\
\text { natural relief } \\
\text { compartments) }\end{array}$ & $\begin{array}{l}\text { Individually defined aggradational, degradational or } \\
\text { disturbed forms shaped by different technogenic } \\
\text { land surfaces genetic types (excavation, landfilling, } \\
\text { sedimentary or erosion surfaces) }\end{array}$ \\
\hline EXAMPLES & $\begin{array}{l}\text { Urban, mining and } \\
\text { agricultural landscaped } \\
\text { ground, "bad lands” etc. }\end{array}$ & $\begin{array}{l}\text { Technogenic plains, } \\
\text { hilltops or slopes modified } \\
\text { by technogenic processes }\end{array}$ & $\begin{array}{l}\text { Landfills, technogenic terraces, induced gullies, } \\
\text { open pits }\end{array}$ \\
\hline $\begin{array}{l}\text { RELATION WITH } \\
\text { GEOMORPHOLOGIC } \\
\text { TAXONOMIC } \\
\text { CLASSIFICATION } \\
\text { (1) }\end{array}$ & $\begin{array}{l}\text { Ross' } 3^{\text {rd }} \text { taxon } \\
\text { (morphologic units or } \\
\text { landform patterns) }\end{array}$ & $\begin{array}{c}\text { Demek's 3rd taxon } \\
\text { (relief types) } \\
* * * \\
\text { Ross' } 5^{\text {th }} \text { taxon (slope } \\
\text { types) and } 4^{\text {th }} \text { taxon } \\
\text { (landform types) }\end{array}$ & $\begin{array}{l}\text { Demek’s 1st and 2nd taxa (genetically } \\
\text { homogeneous surfaces and landforms) } \\
\qquad * * * \\
\text { Ross' 6th taxon (contemporary processes } \\
\text { landforms) }\end{array}$ \\
\hline $\begin{array}{l}\text { RELATED TECHNOGENIC } \\
\text { (ARTIFICIAL) GROUND } \\
\text { (2) }\end{array}$ & $\begin{array}{l}\text { The overall extensive } \\
\text { landscaped ground which } \\
\text { forms parts of the } \\
\text { Anthopostrome (3) }\end{array}$ & $\begin{array}{l}\text { Settings of artificial ground } \\
\text { related to one or more } \\
\text { classes }\end{array}$ & $\begin{array}{l}\text { Specific categories of aggrades, degraded, modified } \\
\text { or mixed technogenic ground }\end{array}$ \\
\hline
\end{tabular}

REFFERENCE MAPPING SCALES

(4)
Reconnaissance and Regional maps (up to 1:25.000)
Detailed (up to 1:10.000) and Specialized maps (up to1:2.500)

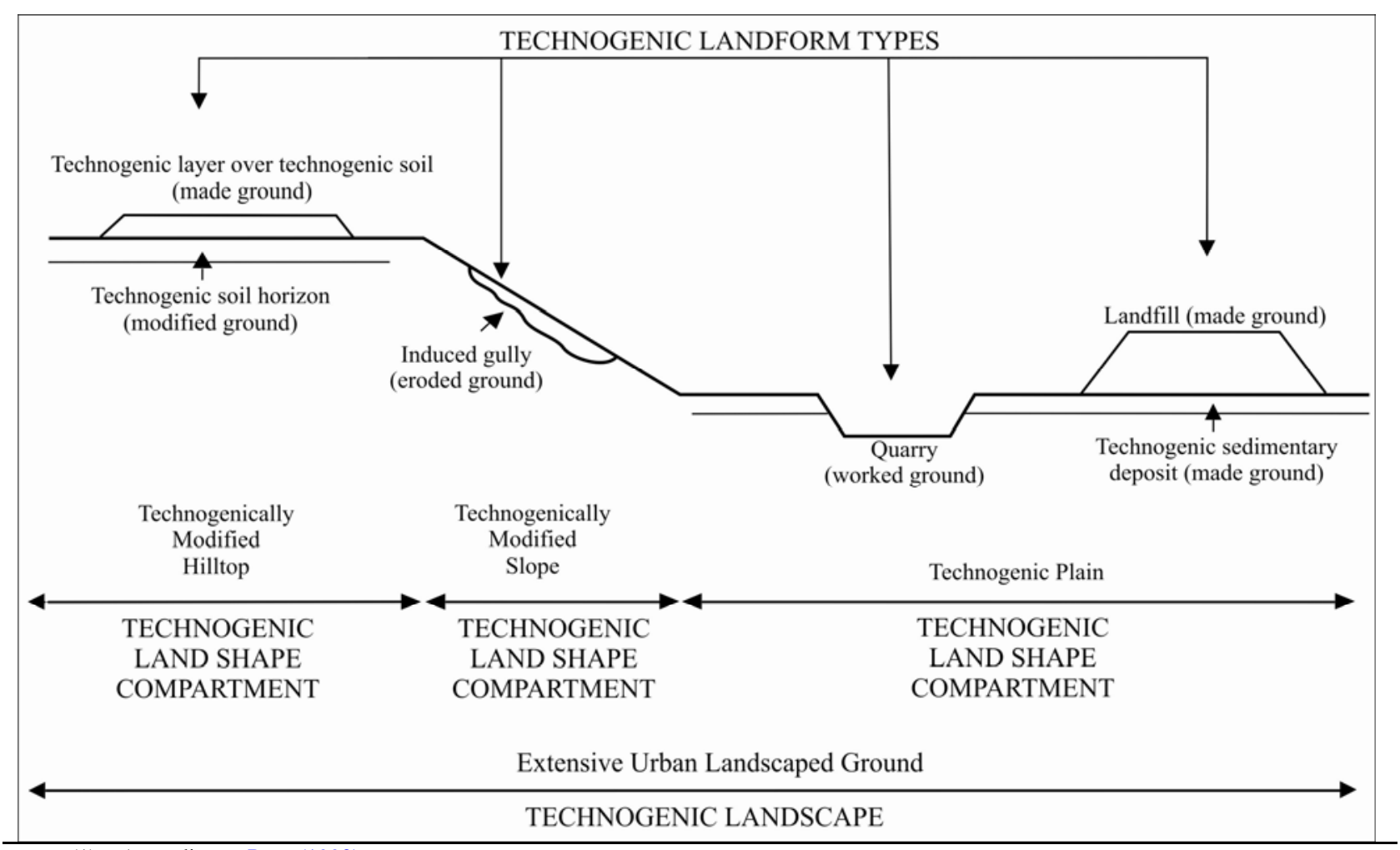

(1) According to Ross (1992).

(2) Based on the BGS artificial ground classification, modified.

(3) According to Passerini (1984).

(4) Nomenclature as used by Barnes \& Lisle (2004). 
Antropoceno - Tecnógeno

Table 7B: Version in Portuguese for taxonomic classification of technogenic relief

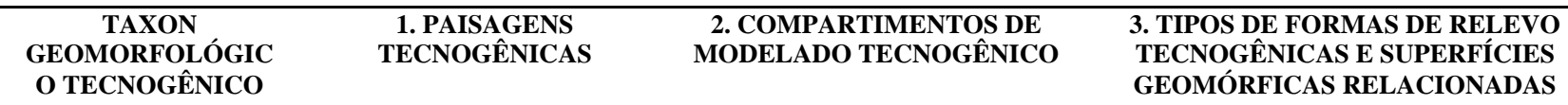

\begin{tabular}{|c|c|c|c|}
\hline CONCEITO & $\begin{array}{l}\text { Áreas amplas com extenso e } \\
\text { típico relevo transformado ou } \\
\text { produzido pela ação humana }\end{array}$ & $\begin{array}{c}\text { Conjuntos de formas de relevo } \\
\text { tecnogênicas associadas a } \\
\text { compartimentos de relevo naturais }\end{array}$ & $\begin{array}{c}\text { Formas de relevo agradacionais, } \\
\text { degradacionais ou movimentadas definidas } \\
\text { por diferentes tipos genéticos de superfícies } \\
\text { tecnogênicas (de escavação, aterramento, } \\
\text { sedimentação ou erosão) }\end{array}$ \\
\hline EXEMPLOS & $\begin{array}{c}\text { Paisagens urbanas, minerárias } \\
\text { ou rurais de terrenos artificiais, } \\
\text { extensos terrenos ravinados, } \\
\text { etc. }\end{array}$ & $\begin{array}{l}\text { Planícies tecnogênicas, topos de } \\
\text { colinas ou vertentes modificadas } \\
\text { por processos tecnogênicos }\end{array}$ & $\begin{array}{l}\text { Aterros, terraços tecnogênicos, ravinas de } \\
\text { induzidas, cavas de mineração }\end{array}$ \\
\hline $\begin{array}{l}\text { RELAÇÃO COM A } \\
\text { CLASSIFICAÇÃO } \\
\text { TAXONÔMICA DAS }\end{array}$ & $\begin{array}{l}3^{\circ} \text { taxon de Ross (unidades } \\
\text { morfológicas ou padrões de } \\
\text { formas) }\end{array}$ & $\begin{array}{c}3^{\circ} \text { taxon de Demek } \\
\text { (tipos de relevos) } \\
* * *\end{array}$ & $\begin{array}{c}1^{\circ} \text { e } 2^{\circ} \text { taxa de Demek (superfícies } \\
\text { geneticamente homogêneas e formas de } \\
\text { relevo) }\end{array}$ \\
\hline $\begin{array}{l}\text { FORMAS DE RELEVO } \\
\text { (1) }\end{array}$ & & $\begin{array}{c}5^{\circ} \text { taxon (tipos de vertentes) e } 4^{\circ} \\
\text { taxon (tipos de formas de relevo) } \\
\text { de Ross }\end{array}$ & $6^{\circ}$ taxon de Ross (formas de processos atuais) \\
\hline $\begin{array}{l}\text { TERRENOS } \\
\text { TECNOGENICOS } \\
\text { (ARTIFICIAIS) } \\
\text { ASSOCIADOS } \\
\text { (2) }\end{array}$ & $\begin{array}{l}\text { Terrenos de paisagens } \\
\text { artificiais que constituem } \\
\text { partes do Antropostroma (3) }\end{array}$ & $\begin{array}{l}\text { Conjuntos de terrenos artificiais } \\
\text { relacionados a um ou mais tipos de } \\
\text { forma de relevo tecnogênica }\end{array}$ & $\begin{array}{c}\text { Categorias específicas de terrenos } \\
\text { tecnogênicos agradativos, degradativos, } \\
\text { modificados e mistos }\end{array}$ \\
\hline $\begin{array}{l}\text { ESCALAS DE } \\
\text { REFERENCIA DE } \\
\text { MAPEAMENTO (4) }\end{array}$ & \multicolumn{2}{|c|}{$\begin{array}{l}\text { Mapas de reconhecimento e } \\
\text { Mapas regionais (escalas 1:25.000 e maiores) }\end{array}$} & $\begin{array}{c}\text { Mapas de detalhe ( } 1: 10.000 \text { ou maiores) e } \\
\text { especializados } \\
(1: 2.500 \text { e maiores })\end{array}$ \\
\hline
\end{tabular}

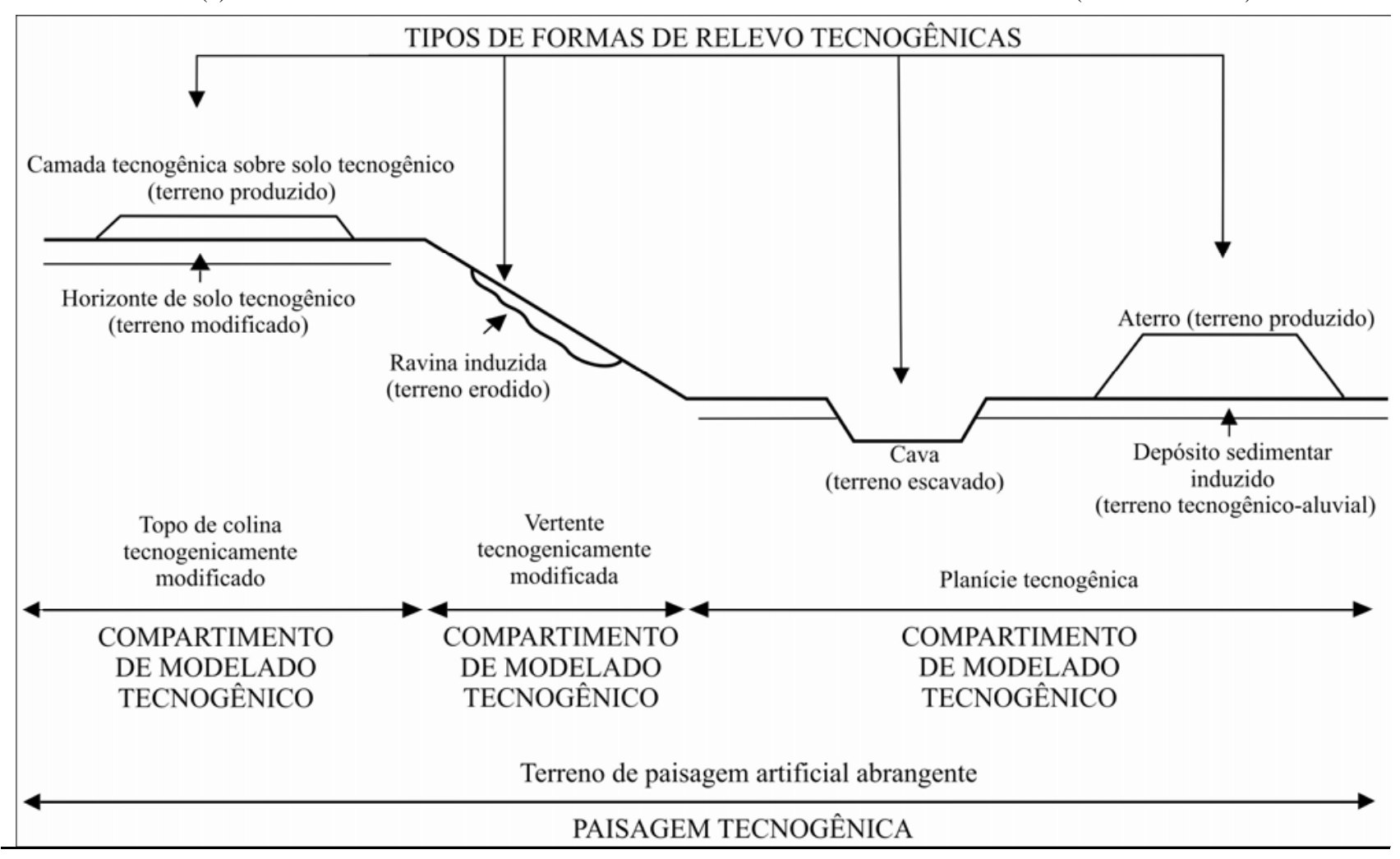

(1) Conforme Ross (1992).

(2) Baseada na classificação de terrenos artificiais do Serviço Geológico Britânico, modificada.

(3) No sentido proposto por Passerini (1984).

(4) Nomenclatura utilizada por Barnes \& Lisle (2004). 


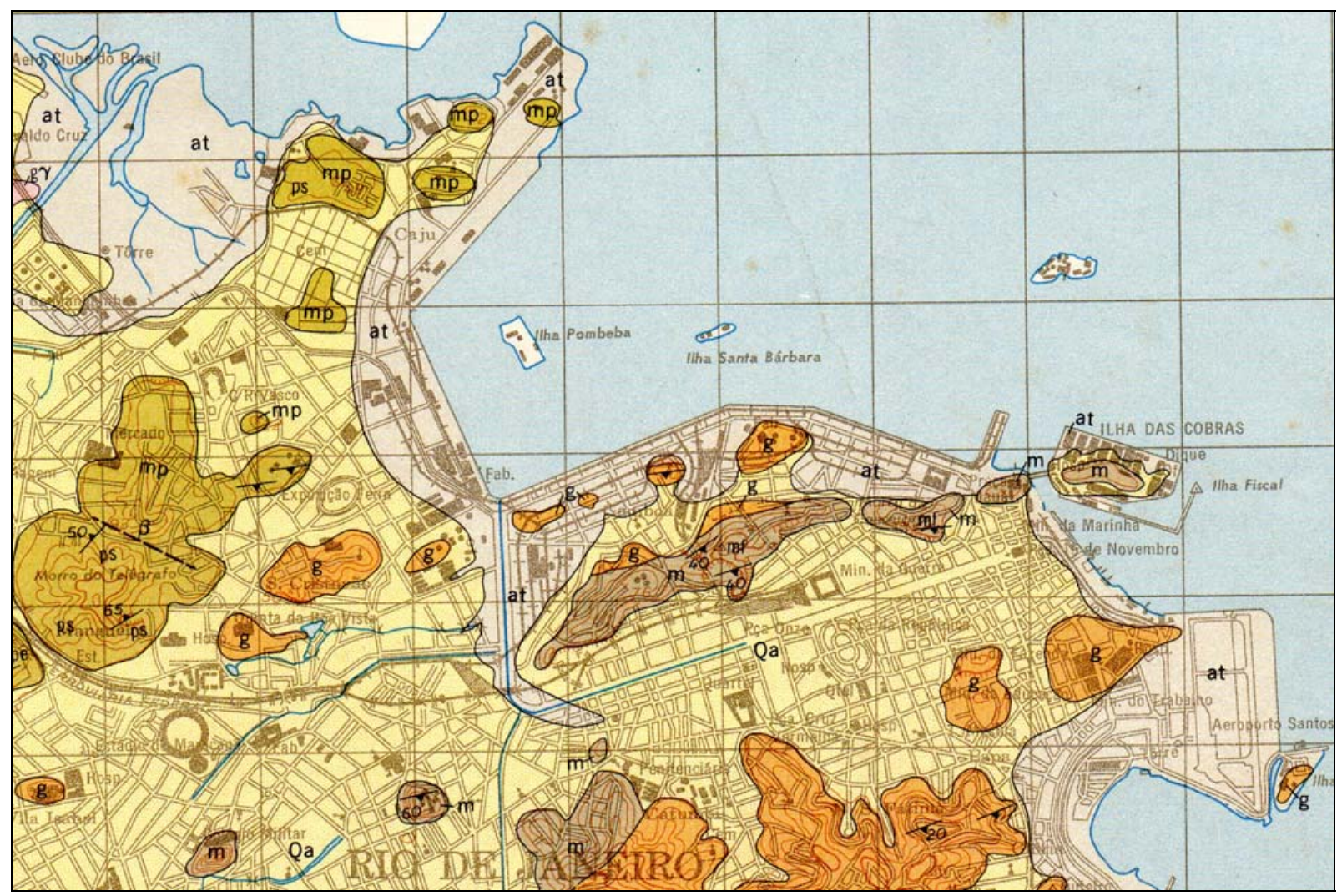

Figure 3: Technogenic land shape compartments: an extract of Guanabara State Geological Map, original scale 1:50.000 (Brazilian Ministry of Mines and Energy, Geology and Mineralogy Division, 1965). The "at" grayish areas near the shore are settings of flat lands (embankments) built up by technogenic deposits (made ground)

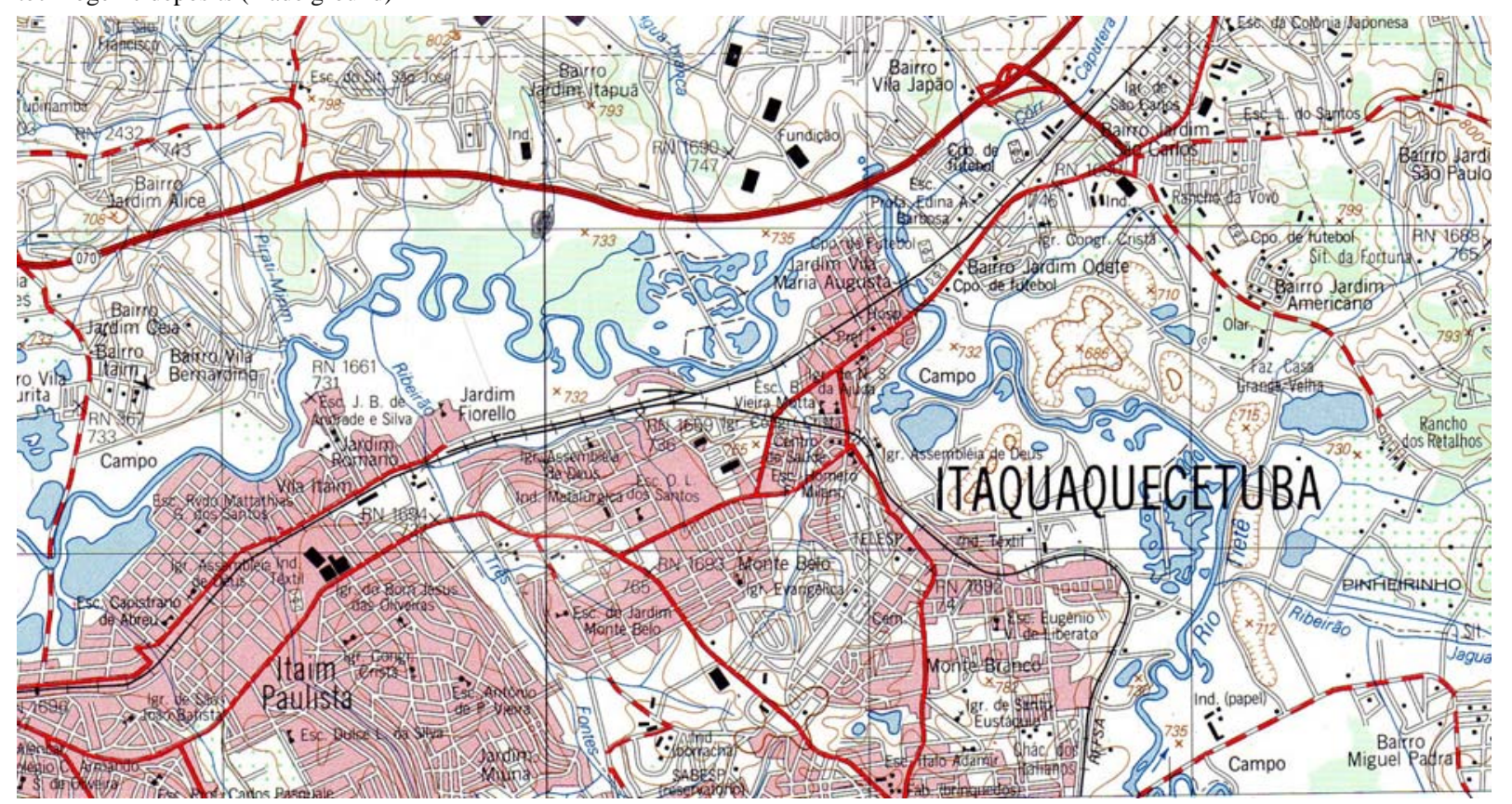

Figure 4: Technogenic landscape : The Tietê River technogenic plain, near São Paulo City, in which can be clearly viewed the worked ground (sand quarries) and technogenic lakes formed upon them. The former alluvial floodplain is even recognizable by the meandering river remaining. Extract of 1:50.000 (original scale) geographic map, Itaquaquecetuba Sheet SF.23-Y-D_I_3 (IBGE - Brazilian Institute of Geography and Statistics, 1984)

Contemporarily, this part of the city has reached a consolidated stage of urbanization, the settlement taking place over several years, in particular the late 1970's and through to the end of the 1980's (Fernandes 1988, Sposito 1990). This urban evolution has allowed the formation of artifact-rich technogenic deposits, such as tile fragments, plastic materials, tissue rests and some garbage (figure 5), that can be classified as urbic materials according to the proposal by Fanning \& Fanning (1989). The sampling of the technogenic deposit was extracted by using a one meter long 6" PVC tube (figure 6), and the material has been excavated from a gully wall. Finally, it is remarkable that in this area the valley flats had also been habitually 
used for domestic garbage and kitchen midden deposal, and this type of technogenic material can be classified as garbic (Fanning \& Fanning 1989), that is, waste material.

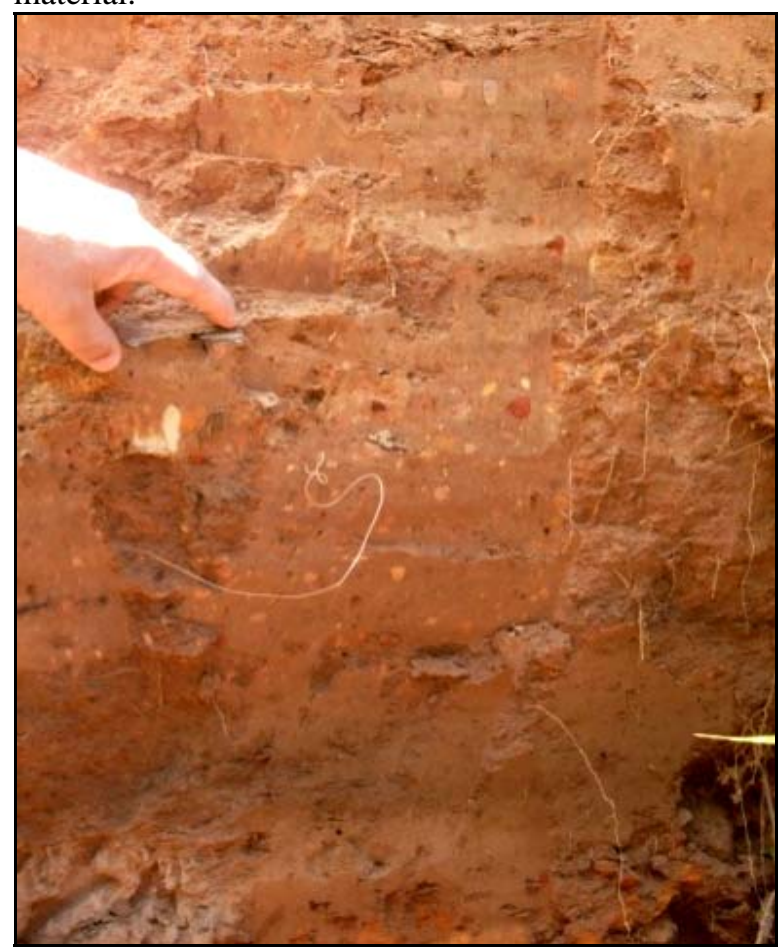

Figure 5: Technogenic deposit found at Alexandrina Park. The presence of artifacts (technogenic fragmented manufactutered materials) can be identified as building refuse (Silva 2012).

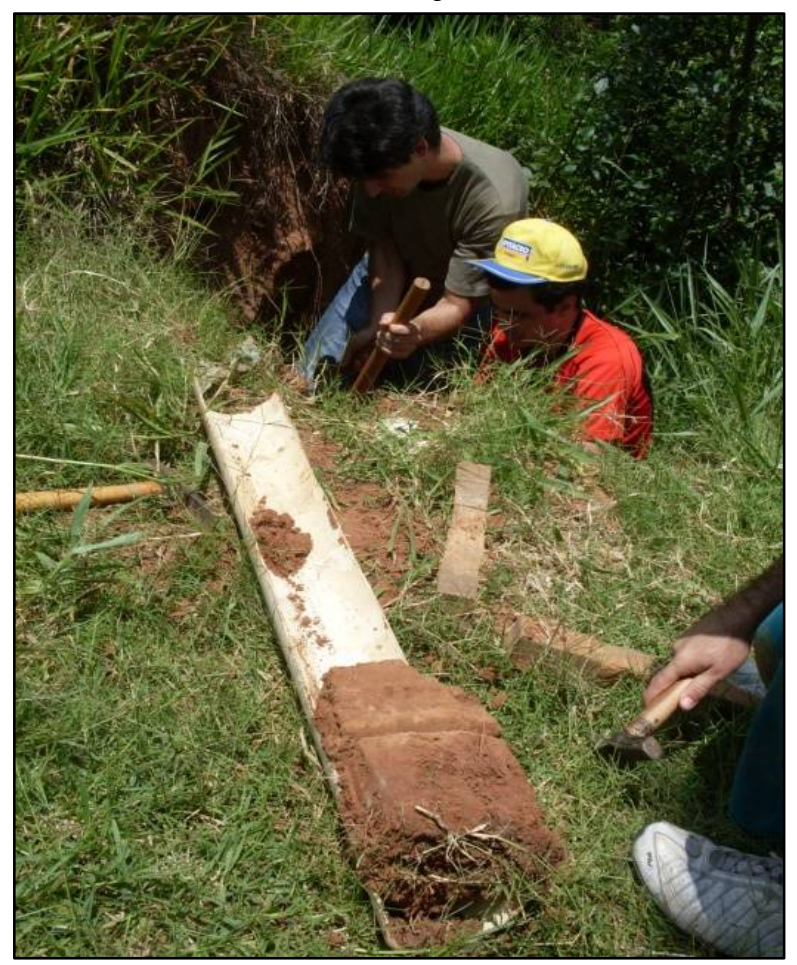

Figure 6: Technogenic material sampling from Alexandrina Park (Silva 2012).

The technogenic deposit cited is nowadays being intensivelly eroded, what is explained by the hypothesis formulated by Oliveira (1990), from whom as the urbanisation processes move forward, the superficial runoff increases (due to street pavements, for example) and the former technogenic deposits can be themselves eroded. In this way the technogenic material can be well deposited on lower portions of the slopes and just in the valley thalweg.

Industrial District I (Antônio Crepaldi area) was formed in the late 1970's and presents different land uses although the main use is industrial, as the district's name indicates. The land occupation has been concentrated along the gentle undulating hilltops, but the hillsides present steeped sloped areas like the ones at the headwaters and the slope basis.

The occurrence of a major domestic waste deposit is another specific feature of the area (figure 7). The deposit has been considered inadequate by the São Paulo State Environment Agency (CETESB 2012), and can be classified as a built up technogenic deposit composed by garbic material, that is, garbage with organic waste able to generate Methane under anaerobic conditions (Fanning \& Fanning 1984). The induced techogenic deposit studied is found just downslope from the waste deposit cited above, and its constituent materials are derived from the erosion processes taking place in the mid slope, induced by human activities. The same PVC tube sampling technique was used in this area, the sampler being inserted into the ground up to a depth of $59 \mathrm{~cm}$ in a gully wall formed by the superficial flow of rain water and of the contaminated water resulting from the waste deposit.

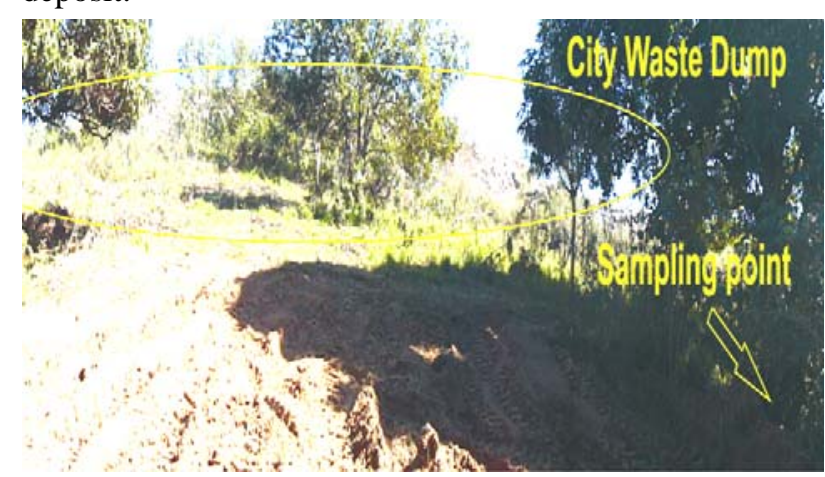

Figure 7: Contemporary view of Presidente Prudente solid waste dump referring to the sampling point of technogenic deposit (Silva 2012).

This deposit can be classified as the induced colluvium-like sedimentary type (see table 4 ), because the human influence in its formation has occurred previously and at an upslope place, turning the downslope technogenic deposition possible due to the action of a superficial runoff. In the studied area there is a large quantity of materials coming from the dump; however, specifically in the deposit just a few traces of these components were fround among the sampled technogenic sedimentary layers.

\subsection{Geomorphologic natural configurations and the geomorphologic technogenic mapping of Presidente Prudente City}

The geomorphologic mapping of Presidente Prudente City was carried out by Nunes et al. (2006) in 1995, 
based on aerial photographs (BASE S.A.). In this map there are outlined land shape compartments as well as the valley flat and slope related landforms.

These compartments and landforms have been outlined without considering the technogenic modifications that have been superimposed over the original landforms. The main issue associated with this is how to include the new technogenic landforms within the former geomorphologic map.

The method employed to resolve the issue was just to insert, into the previous maps, appropriated textures and non shaded polygons to indicate the occurrence of technogenic ground that was found in the landscape. The shaded coloured polygons have remained in the map showing the original land shape compartments.

To identify the technogenic landforms it was necessary to use aerial photographs of two distinct times (1962 and 1995) in 1:25.000 map scale, afterwards complemented by satellite images (Google Earth) from 2013.

After all, the identification and mapping of the technogenic ground and its related landforms was possible using former images and by the investigation of the technogenic layers themselves. These procedures have permitted the inference of the processes that have led to the formation of the technogenic deposits and, as a directly related consequence, the technogenic landforms. In the Industrial District area, the main modifications to the land have been caused through erosion and stream dynamics modification (figure 8).

By observing the aerial photographs it has been possible to view several consequences of the technogenic actions over the landscape. In the 1962 photo it is possible to view a little vegetation and several erosion scars related to the removal of former woodland. As the urbanisation had not started yet in this area, the changes occurred can be associated with rural activities.

In the 1995 aerial photo, which has been used for the geomorphologic mapping, it is just possible to observe the urban-industrial development in the area. Between 1962 and 1995 there were extensive changes to the landscape, as the filling of eroded ground by technogenic materials and the start of new erosion processes. Another remarkable change has occurred to the river dynamics, by the disappearance of stream segments between 1962 until 1995, and the urban development on the former sites of stream sources, that conforms nowadays with hilltops. In this situation it is likely that what has occurred is the direct deposition of technogenic material.

The floodplain has also suffered from sedimentary deposition processes, which can be observed by

\footnotetext{
2 Laboratory of Aerofotogeography e and Remote Sensing Department of Geography - São Paulo University (IS/ many companies). 1962 flight over Presidente Prudente - SP. Aerial photographs (semi-controlled mosaic). Scale: 1:25000. N. 6780 e 6479.

BASE S/A 1995. BASE Aerofotogrametria e Projetos S/A (São Paulo). September 1995 flight over Presidente Prudente - SP. Aerial photographs. Scale1:25000. Fx 04. N 12 e 9.
}

comparing the aerial photos between 1962 and 1995, which also shows the disappearance of stream segments.

The deposition of technogenic materials (wastes and garbage) has been identified by comparing the aerial photographs with the recent Google Earth images, because this kind of deposition has been taking place since 1997, as it has already occurred at Alexandrina Park area (figure 9), as cited above.

According to Mazzini (1997), two specific areas at Alexandrina Park were used for domestic waste deposition, one which had been a former erosion gully, was completely filled by 1978, and the other was the valley flat, which was used as a deposition place until 1987. Beyond the filled gullies other ones have been created already through erosion, and it was observed that many stream channels have been buried.

According to the results of the geomorphologic mapping, the identified relief features can be classified as technogenic landforms of aggraded and degraded types (table 7). In some cases the aggraded forms occur over formerly degraded ground, as in the above described buried erosion gullies.

\section{Final remarks}

In this context, nowadays it is clear that the landscapes produced or modified by humans are not only just visual images, but they have a material basis that has been created directly or indirectly through human activity. These features are specifically geological in that they refer to the new layers of aggraded ground that have been created, and are specifically geomorphologic when the newly created landforms and land shapes are considered.

In other words, humankind is in a broad sense a geological agent just in the way he, changing or creating processes (which implies degradation, aggradation or disturbance of natural land), produces new types of artificial ground recognized as specific landforms. This action has been termed by Chemekov (1983) as geotechnogenesis. This specific aspect of the technogenesis refers to the creation, through human action, of landforms and land shapes in the way which is referred to as morphotechnogenesis (Peloggia 1998).

Understanding the dynamics and mode of work of this new agent is a new challenge for geoscientists. Of course, one of the first tasks for them is to observe, identify, map and classify the products of this original geological action. In this paper, we have proposed support for both the classification and mapping of the technogenic landforms. But it was essentially an exercise that has attempted a first approximation of an original subject. The case study must be understood as being an exploratory study that needs to be further developed as the authors wish this study to be useful as a basic conceptual framework and as a tangible example of application. 

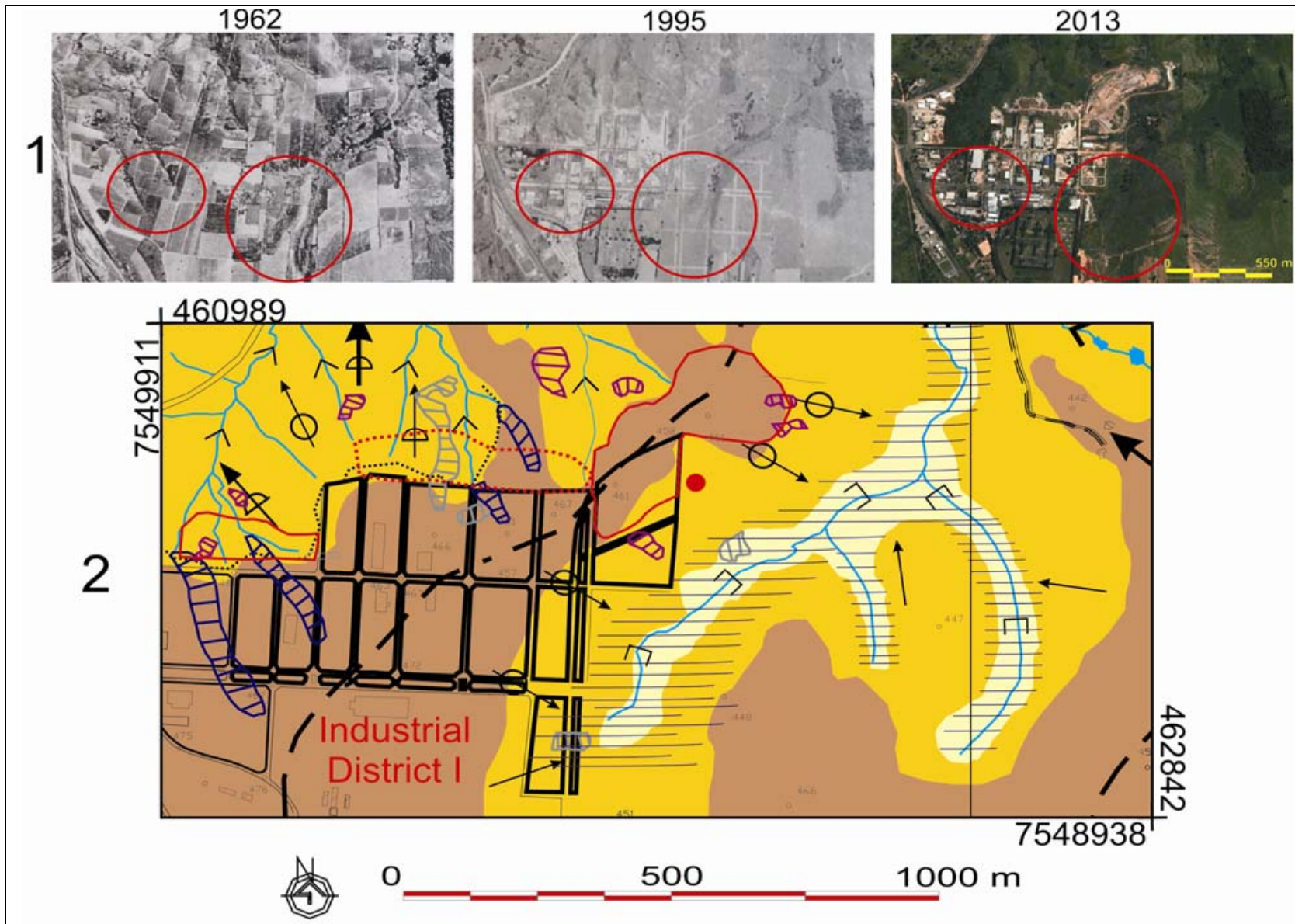

MAP LEGEND

\section{RELIEF COMPARTMENTS}

Slightly undulated top of the convex hill

\section{Concave-convex} slopes domain

Alluvial floodplains and alveolus

\section{HYDRIC FEATURES}

Permanent watercourse

- Weir/Dam

\section{URBANIZED SPACES}

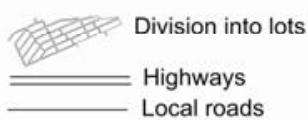

\section{GEOMORPHOLOGIC FEATURES}

..... Watershed line
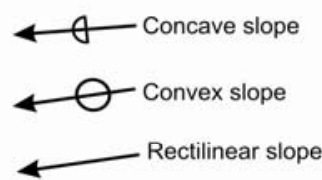

J valley-bottom cradle

$\rightarrow \quad$ Valley with morphology in $V$

$\because \quad$ Drainage headwater with morphology in amphitheater

\section{TECHNOGENIC FORMS AND FEATURES (Approximate contours) \\ Technogenic top and part of slope (deposition of garbic and urbic materials) \\ Technogenic slope (deposition of garbic materials) \\ Technogenic slope (deposition of urbic materials) \\ $\equiv$ Technogenic alluvial floodplains \\ Buried fluvial channels \\ Erosive features present in 1962 that were covered \\ (1D) Erosive features present in 1995}

1- Sequence of images of Industrial District I - Antônio Crepaldi. Highlights of areas of altered valley-bottoms. 1962: Aerial photo scale of 1:25.000 (IS/several companies; obtained with Laboratório de Aerofotogeografia e Sensoriamento Remoto of Geography Department - USP). 1995: Aerial photo scale of 1:25000 (BASE S.A.). 2013: Image Google Earth, 03/04/2013.

2- Cutting of Geomorphologic Map of Urban Perimeter of Presidente Prudente-SP drafted in 2006 (NUNES; FREIRE; PEREZ), adapted with technogenic features and base given by town hall of Presidente Prudente (2010).

Sampling point of technogenic deposit

Org. Érika Cristina Nesta Silva and Joāo Osvaldo Rodrigues Nunes

Figure 8: Technogenic landforms related to land shape compartments in Industrial District I 

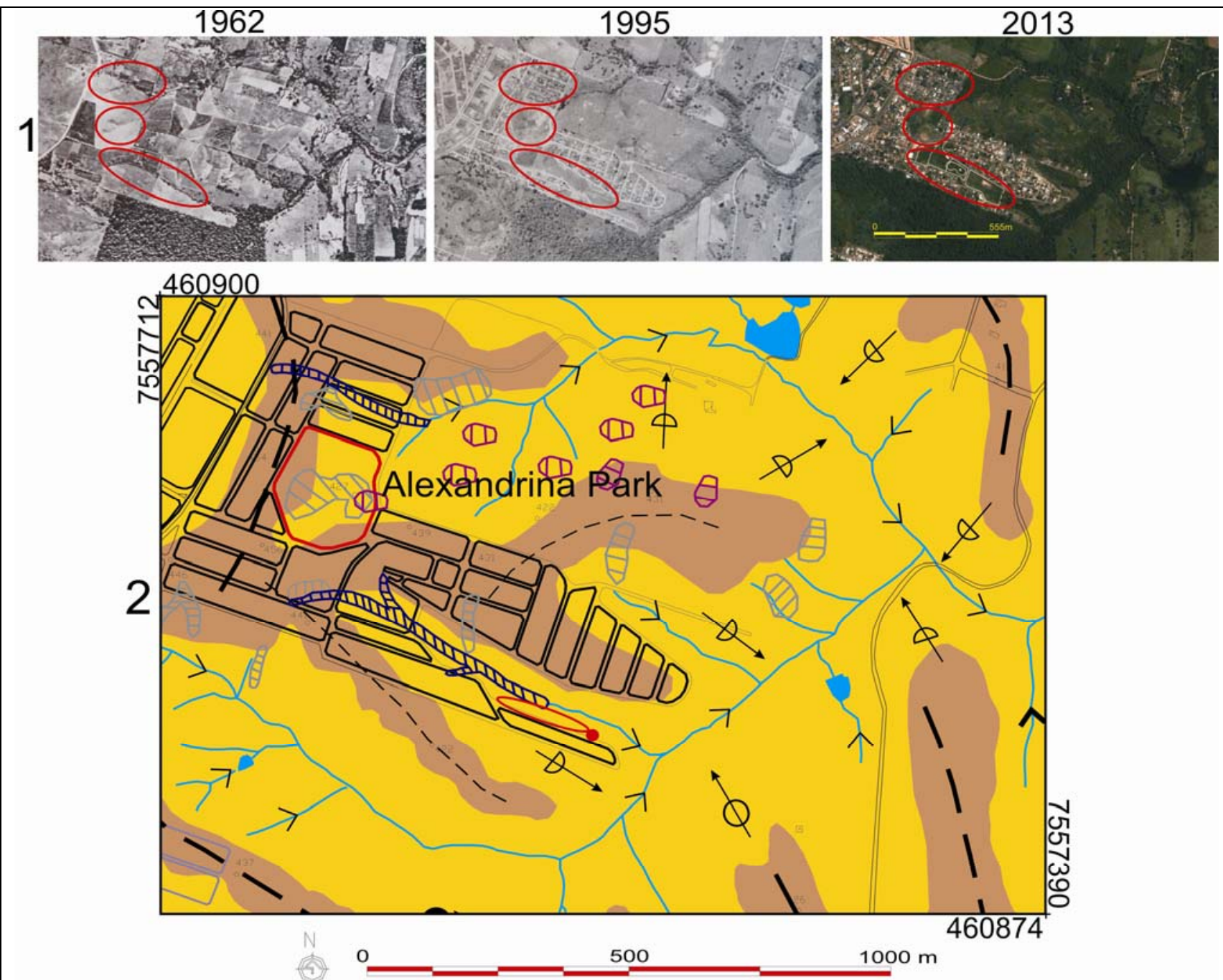

MAP LEGEND

\section{RELIEF COMPARTMENTS}

Slightly undulated top of the convex hill

Concave-convex slopes domain

\section{HYDRIC FEATURES}

\section{Permanent watercourse}

Weir/Dam

URBANIZED SPACES

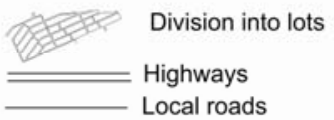

\section{GEOMORPHOLOGIC FEATURES}
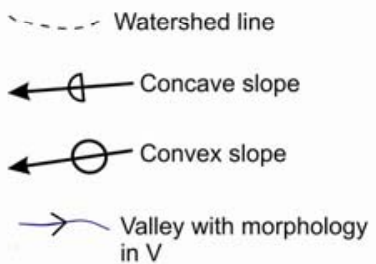

TECHNOGENIC FORMS AND FEATURES (Approximate contours)

$\square$ Area with erosive features recovered by garbic materials

$\infty$ Technogenic slope (deposition of garbic materials)

Buried fluvial channels

Erosive features present in 1962 that were covered

(1D) Erosive features present in 1995

1- Sequence of images of Alexandrina Park. Highlights of the major technogenic changes observed. 1962: Aerial photo scale of 1:25.000 (IS/several companies; obtained with Laboratório de Aerofotogeografia e Sensoriamento Remoto of Geography Department - USP). 1995: Aerial photo scale of 1:25000 (BASE S.A.). 2013: Image Google Earth, 03/04/2013.

2- Cutting of Geomorphologic Map of Urban Perimeter of Presidente Prudente-SP drafted in 2006 (NUNES; FREIRE; PEREZ), adapted with technogenic features and base given by town hall of Presidente Prudente (2010).

Sampling point of technogenic deposit

Org. Ėrika Cristina Nesta Silva and Joăo Osvaldo Rodrigues Nunes

Figure 9: Technogenic landforms associated to land shape compartments at Alexandrina Park 
Antropoceno - Tecnógeno

Table 7: Land shape compartments and related technogenic landforms observed at the mapped areas

\begin{tabular}{|c|c|c|c|c|}
\hline \multirow{3}{*}{\multicolumn{2}{|c|}{$\begin{array}{l}\text { LAND SHAPE } \\
\text { COMPARTMENTS } \\
\text { AND RELATED } \\
\text { TECHNOGENIC } \\
\text { LANDFORMS }\end{array}$}} & \multicolumn{3}{|c|}{ LAND SHAPE COMPARTMENTS } \\
\hline & & \multicolumn{2}{|r|}{ Hills } & \multirow{2}{*}{$\begin{array}{c}\text { Alluvial } \\
\text { floodplains }\end{array}$} \\
\hline & & Tops & Slopes & \\
\hline 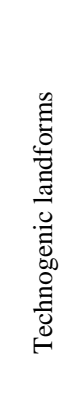 & 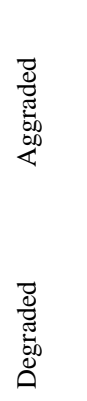 & $\begin{array}{l}\text { Flat made ground } \\
\text { consisting of technogenic } \\
\text { built up deposits } \\
\text { (landfilled surfaces) }\end{array}$ & $\begin{array}{l}\text { Erosion gullies filled with technogenic deposits (Infilled ground } \\
\text { with infilled surfaces) } \\
\text { "V” valleys filled with technogenic deposits (terrace made } \\
\text { ground) and buried stream channels (landfilled surfaces) } \\
\text { Erosion gullies induced by land use (eroded surfaces) }\end{array}$ & $\begin{array}{l}\text { Alluvial deposits } \\
\text { covered by } \\
\text { technogenic } \\
\text { deposits } \\
\text { (terraced made } \\
\text { ground with } \\
\text { landfilled surfaces) }\end{array}$ \\
\hline
\end{tabular}

\section{Acknowledgments}

The authors are grateful to Mr. Brian Begley for his English linguistic support. E. C. N. Silva and J. O. R. Nunes are grateful to FAPESP.

\section{References}

Ab’Saber A.N. 1969. Um conceito de geomorfologia a serviço das pesquisas sobre o Quaternário. Geomorfologia, São Paulo, 18:123.

Araújo A.C.R., Barbosa E.J.S. 2010. A estrada e a paisagem: como a antropização atua sobre o relevo (um ensaio de geomorfologia ambiental). In: Encontro Nacional de Geógrafos, XVI, Porto Alegre, Anais... ABG, 10p. Available in: www.agb.org.br. Acessed on the $12^{\text {th }}$ of December, 2013.

Barnes J.W., Lisle R.L. 2004. Basic Geological Mapping. $4^{\text {th }}$ ed. ,John Wiley \& Sons, Chichester, 184p.

Brown E. 1970. Man shapes the Earth. The Geographical Journal 136(1): 74-85.

CETESB. 2012. Inventário estadual de resíduos sólidos urbanos 2012. (Série Relatórios/ Secretaria do Estado do Meio Ambiente). Available in: http://www.cetesb.sp.gov.br/solo/ publicacoes-e-Relatorios/1- Publicacoes-/-Relatorios. Accessed on the $20^{\text {th }}$ of November, 2013.

Chemekov Y.F. 1983. Technogenic deposits. In: INQUA Congress, 11, Moscow, Abstracts... v.3, p.62

DGM - Divisão de Geologia e Mineralogia - MME/DNPM. 1965. Mapa Geológico do Estado da Guanabara. SF-23-Q-IV-/SF-23W-II-2. 1: 50.000 scale.

Drew D. 1983. Man-Environment processes. George Allen \& Unwin, London, 135p.

Fanning D.S., Fanning M.C.B. 1989. Soil: morphology, genesis and classification. John Wiley \& Sons, New York, 395p.

Goudie A. 1993. Human influence in geomorphology. Geomorphology 7: 37-59.

Goudie A. 1994. The human impact on the natural environment. $4^{\text {th }}$ ed. The MIT Press, Cambridge, 454p.

Goudie A., Viles H. 2010. Landscapes and Geomorphology. Oxford University Press, Oxford, 137p.

Hooke R.L. 1994. On the efficacy of humans as geomorphic agents. GSA Today 4(9): 217/224-225.

Hooke R.L. 1999. Spatial distribution of human geomorphic activity in the United States: comparison with rivers. Earth Surface Processes and Landforms 24(8): 687-692.

Hooke R.L. 2000. On the history of humans as geomorphic agents. Geology 28(9): 843-846.

Instituto de Pesquisas Tecnológicas do Estado de São Paulo - IPT (1981). Mapa geológico do Estado de São Paulo: 1:500.000. São Paulo, v.I, p.46-8; 69 (Publicação IPT 1184).
Nir D. 1983. Man, a geomorphological agent: an introduction to anthropic geomorphology. Keper Publishing House, Jerusalem; D. Reidel Publishing, Dordrecht, 175p.

Nunes J.O.R., Freire R., Perez I.U. 2006. Mapeamento Geomorfológico do perímetro urbano do município de Presidente Prudente-SP. In: Simpósio Nacional de Geomorfologia, VI; I.A.G. Regional Conference on Geomorfology, 2006, Goiânia, Anais... União da Geomorfologia Brasileira; International Association of Geomorphologists, 111p.

Oliveira A.M.S. 1990. Depósitos tecnogênicos associados a erosão atual. In: Congresso Brasileiro de Geologia de Engenharia, 6, Salvador... Anais, ABGE: ABMS, p. 411-416.

Passerini P. 1984. The ascent of the Anthropostrome: a point of view on the Man-Made Environment. Environmental Geology and Water Sciences 6(4): 211-221.

Peixoto M.N.O., Mello E.V., Silva S.M., Moura J.R.S., Lopes C.Q.G., Silva S.T., Pinto C.D. Jr. 2011. Feições tecnogênicas em Volta Redonda (RJ). In: Congresso da Associação Brasileira de Estudos do Quaternário, 13, Anais... ABEQUA, CD-ROM, 6p.

Peloggia A.U.G. 1998. A magnitude e a frequência da ação humana representam uma ruptura na processualidade geológica na superfície terrestre?. Geosul 14( 27): 54-60 (Edição Especial: II Simpósio Nacional de Geomorfologia).

Peloggia A.U.G. 2005a. A ação geológica do homem nos clássicos da geologia, com especial atenção aos Principles of Geology de Lyell. In: Congresso da Associação Brasileira de Estudos do Quaternário, 10, Guarapari (ES), Anais... ABEQUA, CD-ROM, 7p. Avaliable in http://www.abequa.org.br/trabalhos/ 0305_alex_peloggia.pdf. Accessed on the 20th of November, 2013.

Peloggia A.U.G. 2005b. A cidade, as vertentes e as várzeas: a transformação do relevo pela ação do homem no Município de São Paulo. Revista do Departamento de Geografia (FFLCHUSP) 16: 24-31.

Peloggia A.U.G., Oliveira A.M.S., Oliveira A.A., Silva E.C.N., Nunes J.O.R.. Technogenic Geodiversity: a proposal on the classification of artificial ground. Quaternary and Environmental Sciences, submitted.

Peloggia A.U.G., Oliveira A.M.S. 2005. Tecnógeno: um novo campo de estudos das geociências. In: Congresso da Associação Brasileira de Estudos do Quaternário, 10. Guarapari (ES)... Anais, ABEQUA, CD-ROM, 4p. Avaliable in: http://www.abequa.org.br/trabalhos/0268_tecnogeno.pdf. Accessed on the $5^{\text {th }}$ of November, 2013.

Peloggia A.U.G., Oliveira A.M.S. The Anthropocene and the Technogene: stratigraphic temporal implications of the geological action of mankind. Quaternary and Environmental Sciences, submitted.

Price S.J., Ford J.R., Cooper A.H., Neal C. 2011. Humans as major geological and geomorphological agents in the Antropocene: the 
Antropoceno - Tecnógeno

significance of artificial ground in Great Britain. Phil. Trans. $R$. Soc. A 369: 1056-1086.

Price S.J., Ford J., Kessler H., Cooper A., Humpage A. 2004. Artificial ground: mapping our impact on the surface of the Earth. Earthwise 20: 30-32.

Rosenbaum M.S., Mcmillan A.A., Powell J.H., Cooper A.H., Culshaw M.G., Northmore K.J. 2003. Classification of artificial (man-made) ground. Enginnering Geology 69(3-4): 399-409.

Rohde G.M. 1996. Epistemologia Ambiental: uma abordagem filosófico-científica sobre a efetuação humana alopoiética. Porto Alegre: EDIPUCRS, 231p.

Ross J.L.S. 1992. O registro cartográfico dos fatos geomórficos e a questão da taxonomia do relevo. Revista do Departamento de Geografia, (FFLCH-USP) 6: 17-29.

Sherlock R.L. 1922. Man as a geological agent: an account of his action on inanimate nature. H.F. \& G. Witherby, London, 372p.

Silva E.C.N. 2012. Formação de depósitos tecnogênicos e relações com o uso e ocupação do solo no perímetro urbano de Presidente Prudente - SP. Dissertação de Mestrado. Pós-Graduação em Geografia, Faculdade de Ciência e Tecnologia, Universidade Estadual Paulista, Presidente Prudente. 183p. Available in http://www.athena.biblioteca.unesp.br/F/?func=find-b0\&local_base=BPP. Accessed on the $14^{\text {th }}$ of November, 2013.

Sposito E.S. 1990. Produção e apropriação da renda fundiária urbana em Presidente Prudente. Tese de Doutorado. Faculdade Filosofia Letras e Ciências Humanas, Universidade de São Paulo, São Paulo, 230p.

Trenhaile A.S. 2004. Geomorphology: a Canadian perspective. Don Mills (Ontario): Oxford University Press, 440p.

Vita-Finzi C. 1993. Physiographic effects of Man. In: The New Encyclopaedia Brittanica, Macropaedia, $15^{\text {th }}$ ed., v.20, p.22-26.

Wilkinson B.H. 2005. Humans as geologic agents: a deep time perspective. Geology 33(3): 161-164.

Recebido 18 de dezembro de 2013 Aceito 01 de agosto de 2014 